\title{
Demand relaxation in supplier selection processes
}

\section{Relaxamento de demanda em processos de seleção de fornecedores}

\author{
Felipe Vizzoto ${ }^{1}$ (1) \\ José Vicente Caixeta Filho²
}

\section{GESTÃO PRODUCÃ̃O}

ISSN 0104-530X (Print) ISSN 1806-9649 (Online)

How to cite: Vizzoto, F., \& Caixeta Filho, J. V. (2019). Demand relaxation in supplier selection processes. Gestão \& Produção, 26(4), e3826. https://doi.org/10.1590/0104-530X3826-17

\begin{abstract}
Supplier selection processes generally evaluate several criteria in order to fulfill a demand. But, what if the demand itself could be rethought, spreading the possibilities of acquisition? What are the impacts in cost and utility of buying objectives instead of pre-determined materials? This work tries to expand this discussion with a mathematical programming approach to selecting suppliers with demand relaxation. The requirements for the framework development and application in purchasing departments are also pointed out. Its adoption in association with combinatorial auctions concepts in a hypothetical but realistic context suggests a high potential to cost reduction with no significant utility decrease.
\end{abstract}

Keywords: Supplier selection; Purchasing; Demand relaxation.

Resumo: Os processos de seleção de fornecedores geralmente avaliam um conjunto de critérios afim de melhor atender uma demanda. Mas e se a própria demanda pudesse ser repensada, expandindo as possibilidades de aquisição? Quais os impactos em custo e utilidade de se comprar objetivos ao invés de materiais pré-determinados? Este trabalho introduz essa discussão por meio de uma abordagem em programação matemática para seleção de fornecedores com relaxamento da demanda. Os pré-requisitos para seu desenvolvimento e aplicação em um departamento de suprimentos também são apontados. A adoção do modelo proposto em associação com conceitos de leilões combinatórios em um caso hipotético, mas realista, sugere um alto potencial para redução de custos sem redução significativa na utilidade.

Palavras-chave: Seleção de fornecedores; Compras; Relaxamento da demanda.

\section{Introduction}

Cost reduction and supplier selection are today as important and complex as they have never been. Trends like outsourcing and globalization, associated with internet and organizational sophistication, highlighted the impacts of decisions related to these issues and increased the complexity of making them (Weber \& Current, 1993; De Boer et al., 2001; Christopher, 2012).

Two relevant factors are derived from these realignments. First, an emerging protagonism made purchasing departments, responsible for hiring suppliers and managing these contracts' costs, shift from administrative, clerical functions to integrated and strategic. From this point on, purchasing's functions, organization and position within the companies have dramatically changed (Gadde \& Håkansson, 1994; Zheng et al., 2007; Wagner \& Kemmerling, 2014). Secondly, the greater complexity in addressing these tasks motivated the development of innumerous approaches involving mathematical programming (MP) in the supplier selection context (Sonmez, 2006).

Although plural and rich in successful applications, the works reported in the revised literature, to the best of our knowledge, ignore two important precedent questionings: (1) what are the impacts in cost and utility of buying "objectives" instead of materials pre-determined by the departments that will use them? (2) which characteristics purchasing departments have to gather to implement the proposed strategies? Promoting a relaxation of demand towards objectives

\footnotetext{
${ }^{1}$ Escola Politécnica, Universidade de São Paulo - USP, Av. Professor Almeida Prado, Travessa 2, 128, CEP 05508-900, São Paulo, SP, Brasil, e-mail: felipe.vizzoto@gmail.com

${ }^{2}$ Escola Superior de Agricultura "Luiz de Queioz" - ESALQ, Universidade de São Paulo - USP, Av. Pádua Dias, 11, CEP 13418-900, Piracicaba, SP, Brasil, e-mail: jose.caixeta@usp.br
}

Received Feb. 27, 2017 - Accepted Sept. 20, 2017

Financial support: None. 
can potentially enhance the results. Also, approaches are more practical when the requirements for their application are clearly stated. In order to fulfill these gaps, this work designs an approach based on mathematical programming to promote demand relaxation while selecting suppliers. Focused in cost reduction with utility maintenance, the essential characteristics that supply chain departments may have to employ it are also pointed out in a comprehensible step by step framework.

The article is organized as follows: section 2 presents the characteristics referred in the literature as critical for supply chain departments' success and the main modeling configurations for vendor selection using mathematical programming. Section 3 details the proposed approach. Section 4 provides a numerical example and its results are evaluated with regards to the pre-defined objectives. Section 5 concludes the article.

\section{Literature drives approach designing}

\subsection{Critical characteristics to thriving purchasing departments}

The literature on purchasing is rich in development models and sources of competitive advantage. A brief review led to a set of five key-features for the appropriate shaping of purchasing departments that are useful for the application of the methodology proposed in this study. Interdepartmental cooperation and integration is vital for constructing purchasing strategies convergent to the organization interests (Narasimhan \& Das, 2001; González-Benito, 2007; Stank et al., 2011; Driedonks et al., 2014; Swink \& Schoenherr, 2015). Still regarding the relationship of supply chain areas with the other organizational cells, it is fundamental for it to be well positioned in the company's hierarchy, influencing relevant decisions and integrated to the strategic planning process (Reck \& Long, 1988; Pearson \& Gritzmacher, 1990; Heckmann et al., 2003; Brandmeier \& Rupp, 2010; Ellinger et al., 2011).

Considering the amount of successful cases presented in the literature (see section 2.2) and researches on supply chain talent (Dubey \& Gunasekaran, 2015; Derwik et al., 2016), it is reasonable to suggest that, besides sophisticated software and efficient information technology systems, thriving purchasing departments' personnel make use of advanced decision analysis methods. Usually based on operations research and statistics, they enhance the accuracy of the decision-making process. Developing strategic alliances and a collaborative environment with the right suppliers is also meant to be a source of competitive advantage (Flynn et al., 2010; Stank et al., 2011). Such initiatives are generally time and money intensive, therefore potential partners should be carefully chosen to avoid wastes and minimize disruption risks (Lambert et al., 1996; Cousins, 1999; Chen et al., 2004).

Finally, no purchasing area is likely to succeed without a solid investment in human capital. Hiring the right employees, granting professional training and properly managing human resources have a direct relation with the results obtained (Carter \& Narasimhan, 1996; Van Weele et al., 1998; Brandmeier \& Rupp, 2010; Van Hoek \& Wagner, 2013; Derwik et al., 2016). Other features are referred as crucial to obtaining good results, like the constitution of cross-functional teams and suppliers' continuous evaluation, just to mention two of them. However, they were not further explored due to the lack of direct linkage to the framework designing. The listed factors, on the other hand, will have a fundamental role on the strategy implementation.

\subsection{Vendor selection MP models: the incorporation of decision criteria, economies of scope and scale}

Several MP models where developed to deal with the supplier selection problem, as shown in at least four literature review works available in the literature (De Boer et al., 2001; Sonmez, 2006; Ho et al., 2010; Chai et al., 2013). Although none of them goes through demand relaxation, important insights can be taken from their findings. Special attention will be devoted to the ways by which decision criteria are incorporated to the models, as well as how do economies of scope (also referred as synergetic effects) and scale are captured.

Even though supplier selection is naturally a multiple criteria decision, it has been treated for some time as a single objective problem. The pioneer works in the application of MP in the vendor selection process are generally structured to maximize or minimize a single criterion, traditionally cost. Other criteria and operational issues only restrict the objective function (Pan, 1989; Jayaraman et al., 1999). When MP is associated with Total Cost of Ownership (TCO) the cost analysis goes beyond. In this case, cost remains as the unique decision criterion in the objective function. The fundamental difference is that TCO considers all the costs incurred along the whole chain. Acquisition, usage, maintenance and even quality patterns are quantified and converted into costs (Ellram, 1995; Degraeve \& Roodhooft, 1999; Walterbusch et al., 2013; Caniato et al., 2015).

Multiple criteria decision making approaches are hegemonic in the recent literature. The association between MP and Multiattribute Utility Methods generally produces models in which a single parameter represents all the relevant criteria. Analytic 
Hierarchy Process (AHP) and Analytic Network Process (ANP) are illustrative examples of methods widely employed to weigh decision criteria and rank the suppliers according to its consolidated results. In these structures, some criteria can also appear as restrictions to the model (Ghodsypour \& O'Brien, 1998; Lin et al., 2011; Dweiri et al., 2016). Another popular manner of addressing the problem is Multi Objective Programming. In this case, the objective function is decomposed in as much functions as the decision criteria are. Restrictions usually take care of operational aspects only (Weber \& Current, 1993; Wadhwa \& Ravindran, 2007; Amin \& Zhang, 2012; Jadidi et al., 2014).

Each of the referred methods has its pros and cons (Table 1). In this work, we have decided to apply an adaptation based on all we've seen. The objective function is composed by two criteria weighed equally in a ratio, cost and utility. Utility represents objectively the most important quality decision criteria. All the other criteria are calibrated by managers to restrict the objective function results, enabling subjective attributes and minor peculiarities to be captured. This adaptation is intended to preserve the straightforwardness of the approach, while empowering qualitative aspects. The trade-off analysis between the two main criteria is inherent to the quotient. To assess it for the other criteria, scenarios must be built.

With the relevance of economies of scope and scale for the competitiveness of an organization in mind, we've decided to include in the model concepts of combinatorial auctions. Other techniques used to take advantage of scale and scope were also investigated (Benton \& Park, 1996; Xia \& Wu, 2007), but combinatorial auctions proved to be more holistic and functional, with several successful applications in literature (Hohner et al., 2003; Catalán et al., 2009; Yu \& Wong, 2015; Yu et al., 2017).

\section{Demand relaxation and the mathematical model}

Choosing the decision attributes and designing a mathematical model that represents faithfully the reality are crucial steps for the success of a vendor selection process. However, these are only developments of a strategy to better meet a demand. What if the demand was narrowly assessed by an anachronistic technical department? We would probably select the best supplier to provide the wrong material. What are the impacts of smoothening materials' demand towards the acquisition of objectives?

In order to deepen this discussion, we propose a method for demand relaxation. In opposition to passively acquiring pre-determined materials chosen by the technical department, purchasing must understand which needs they are intended to fulfill, group the homologated options set on purpose niches and establish maximum and minimum quantities for each material in each niche. By following this procedure, we expect to appropriately fulfill the reported needs while reducing the acquisition costs.

To pursue these tasks in technically complex contexts, purchasing departments must congregate a set of peculiar features. Besides, it is necessary to complement this method with supplier selection concepts, including mechanisms to exploit economies of scope and scale. As discussed in section 2.2, the mathematical model, a mixed integer programming, brings in its objective function a ratio equally weighted between cost and utility, while the other criteria and operational issues are presented as restrictions.

Table 1. Pros and cons of supplier selection methods.

\begin{tabular}{|c|c|c|}
\hline Methods & Advantages & Disadvantages \\
\hline \multirow[t]{2}{*}{ Single Objective Programming } & Simplicity & Superficial analysis of other criteria \\
\hline & Multifunctional & $\begin{array}{l}\text { Trade-offs between criteria are } \\
\text { hampered }\end{array}$ \\
\hline \multirow[t]{2}{*}{ MP + Total Cost of Ownership } & Objective & Complex \\
\hline & Holistic treatment of costs & $\begin{array}{l}\text { Requires extensive tracking and } \\
\text { maintenance of cost data }\end{array}$ \\
\hline \multirow[t]{2}{*}{$\begin{array}{l}\text { MP + Multiattribute Utility } \\
\text { Methods }\end{array}$} & $\begin{array}{l}\text { Fits nicely to cases in which } \\
\text { intangible factors are relevant to } \\
\text { decision }\end{array}$ & Results are relative \\
\hline & $\begin{array}{l}\text { Force trade-offs to be made by } \\
\text { management }\end{array}$ & $\begin{array}{l}\text { Depends on subjective assessments, } \\
\text { difficult to prove its effectiveness }\end{array}$ \\
\hline \multirow[t]{2}{*}{ Multi Objective Programming } & $\begin{array}{l}\text { Results are not relative and preserve } \\
\text { their dimensional units }\end{array}$ & $\begin{array}{l}\text { Above two criteria, trade-off analysis } \\
\text { becomes complicated }\end{array}$ \\
\hline & $\begin{array}{l}\text { Non-dominated solutions allow } \\
\text { decisions to be made, instead of pre- } \\
\text { shaped optimum scenarios }\end{array}$ & $\begin{array}{l}\text { Objective functions weighs are } \\
\text { subjective }\end{array}$ \\
\hline
\end{tabular}

Source: Elaborated by the authors. 
Concepts of combinatorial auctions are employed to allow the incorporation of efficiency gains derived from scale and scope.

The "step by step" of the approach detailed in mathematical language (Figure 1) and the notations used in the formulation of model are stated below.

The framework is presented in an evolutionary basis. Equations 1 and 2 represent the conventional acquisition approach without operational restrictions. With set $j$ input, purpose niches are constituted, converting the previous Equations in 3 and 4. Maximum and minimum usage for each product in each niche are disciplined by Equations 5 and 6 . Afterwards, Equations from 7 to 14 are conceived by the insertion of set $\mathrm{L}$, parameters $C F_{i k}$ and $P P_{i k}$ and the binary variable $B P_{k l}$. The first allows suppliers to make two different offers and the last guarantees that a single one will be chosen. The referred parameters, in turn, regulate the conditions for the proposals to be accepted or rejected. Parameter $P P_{i k}$ becomes the reference for the combinatorial acquisition package, here referred as "Portfolio Proposal". Finally, 15 to 20 are responsible for assuring the operational consistency of the results.
Without the mastery of advanced decision analysis platforms (A) it is unlikely that any purchasing department can structure models of this nature. Qualification of human capital (B) provides purchasing with the necessary technical authority to point out consistent alternative pathways in demand fulfillment, which in association with interdepartmental cooperation (C), produces the perfect environment for reaching consensus on the suitability of the purpose niches designed. Hierarchical empowerment (D) is essential to influence the settlement of maximum and minimum parameters. At this stage, each department tends to direction decisions towards its own, isolated objectives. In that sense, purchasing's rightful mediation is capital to avoid this self-defeating behavior. Lastly, allying combinatorial auctions to the basic model requires discernment regarding the convenience of establishing a strategic alliance and with whom it should be done (E). Economies of scale and scope can lead to a reduction on the supplier base, which increases the disruption risks. Analysis should be done to evaluate if the situation calls for a strategic relationship and, if so, which are the eligible suppliers.

The strengths and limitations of this approach are analyzed in a hypothetical case.

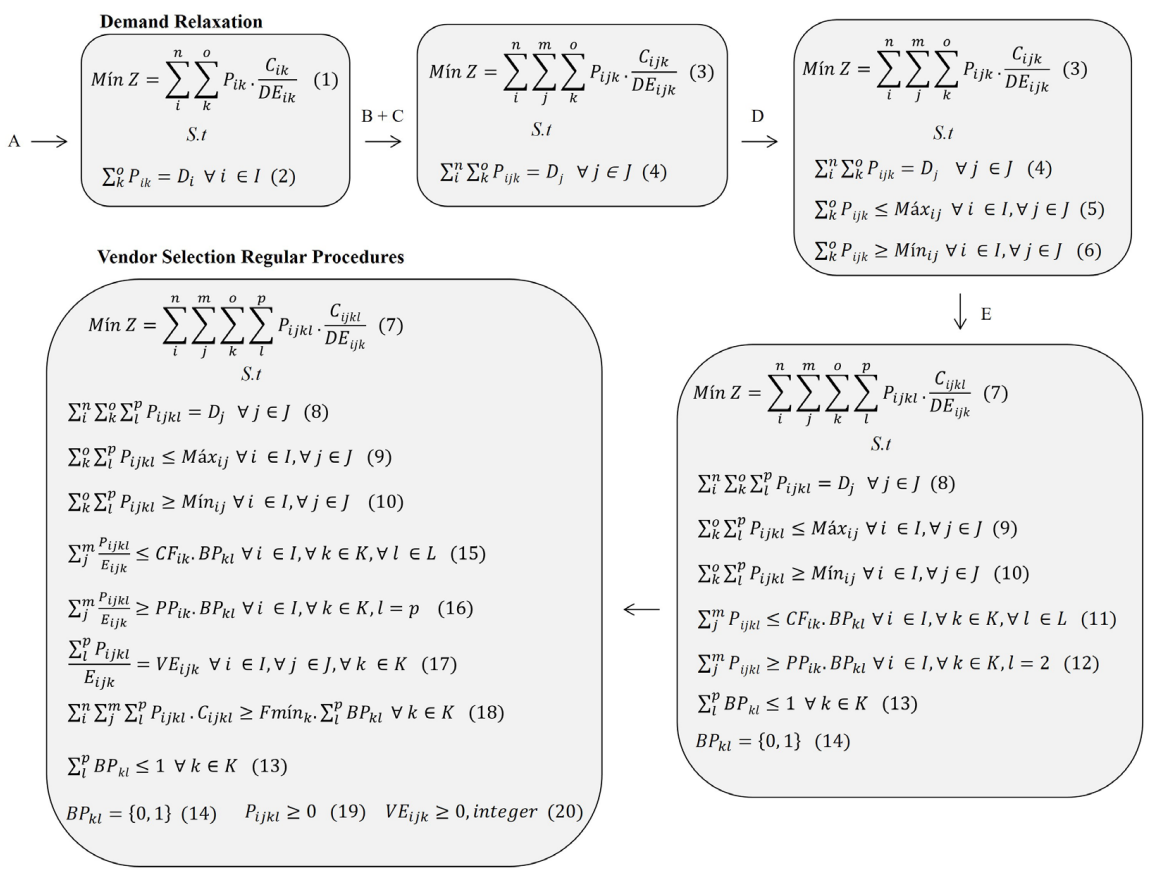

Figure 1. Vendor selection approach with demand relaxation and its application requirements. Where: $I=$ Products from $i \ldots n$; $J=$ Purpose niches from $j \ldots m ; K=$ Suppliers from $k \ldots o ; L=$ Proposals $l$ and $p ; C F_{i k}=$ Supply capacity of product $i$ by supplier $k ; C_{i k}=$ Cost of product $i$ by supplier $k ; C_{i j k}=$ Cost of product $i$, in niche $j$, by supplier $k ; C_{i j k l}=$ Cost of product $i$, in niche $j$, by supplier $k$, in proposal $l ; D E_{i k}=$ Utility of product $i$, by supplier $k ; D E_{i j k}=$ Utility of product $i$, in niche $j$, by supplier $k ; D_{i}=$ Demand for product $i ; D_{j}=$ Aggregate demand in niche $j$; Máx $x_{i j}=$ Maximum usage of product $i$ in niche $j$; $\operatorname{Min}_{i j}=$ Minimum usage of product $i$ in niche $j ; P P_{i k}=$ Portfolio proposal of product $i$ by supplier $k ; F m i n_{k}=$ Minimum order to supplier $k ; E_{i j k}=$ Package content of product $i$, in niche $j$, by supplier $k ; V E_{i j k}=$ Integer variable associated to product $i$, niche $j$ and supplier $k ; B P_{k l}=$ Integer variable associated to supplier $k$ and proposal $l ; P_{i k}=$ Volume acquired of product $i$ from supplier $k ; P_{i j k}=$ Volume acquired of product $i$, for niche $j$, from supplier $k ; P_{i j k l}=$ Volume acquired of product $i$, for niche $j$, from supplier $k$, in the proposal $l ; Z=$ Total cost per utility acquired; A = Mastery of advanced decision analysis tools; $\mathrm{B}=$ Interdepartamental cooperation; $\mathrm{C}=$ Investment in human capital; $\mathrm{D}=$ Hierarchical Empowerment; $\mathrm{E}=$ Discernment for strategic alliances development; 


\section{Agrochemicals acquisition for sugarcane mills in Brazil}

\subsection{Context and approach construction}

The segment selected has challenges that fairly fit in the ones the approach attempts to overcome. Sugarcane mills produce sugar, ethanol and energy. In Brazil, ethanol and energy have its selling prices directly or indirectly controlled by the government. Sugar, in turn, is a commodity with prices defined in the stock market. Considering that, there is a significantly higher pressure in these industries for cost rationalization, since selling prices are unmanageable. A relevant part of these costs comes from the usage of agrochemicals. This market, in turn, is an oligopoly dominated by five multinational corporations. The heavy investments required in research and development work as entry barriers for new entrants, reducing competition. In addition, the prevalence of patented products makes the prices highly controlled. These factors configure a situation in which an industry dependent of cost rationalization is conditioned to another that has its selling prices virtually incompressible. Undoubtedly, a fertile field for sophisticated purchasing approaches.

Classically, the crop production department requests purchasing to buy a set of agrochemicals. Purchasing's role, in this context, is reduced to selecting the suppliers $k$ to fulfill the demand for the agrochemicals $i, D_{i}$. The first step to transgress this traditional procedure is to question the actual need for $D_{i \text {. }}$ To do so, it is important to understand the reason $j$ why $i$ is being required. The application of this concept converts $D_{i}$ into $D_{j}$, that is, the demand is no longer driven to the acquisition of a particular agrochemical $i$, but to a group of agrochemicals $(i, i+1, \ldots, n)$ capable of delivering what is intended by $j$ (Figure 2). By doing that, the possibilities' universe is expanded, so is the

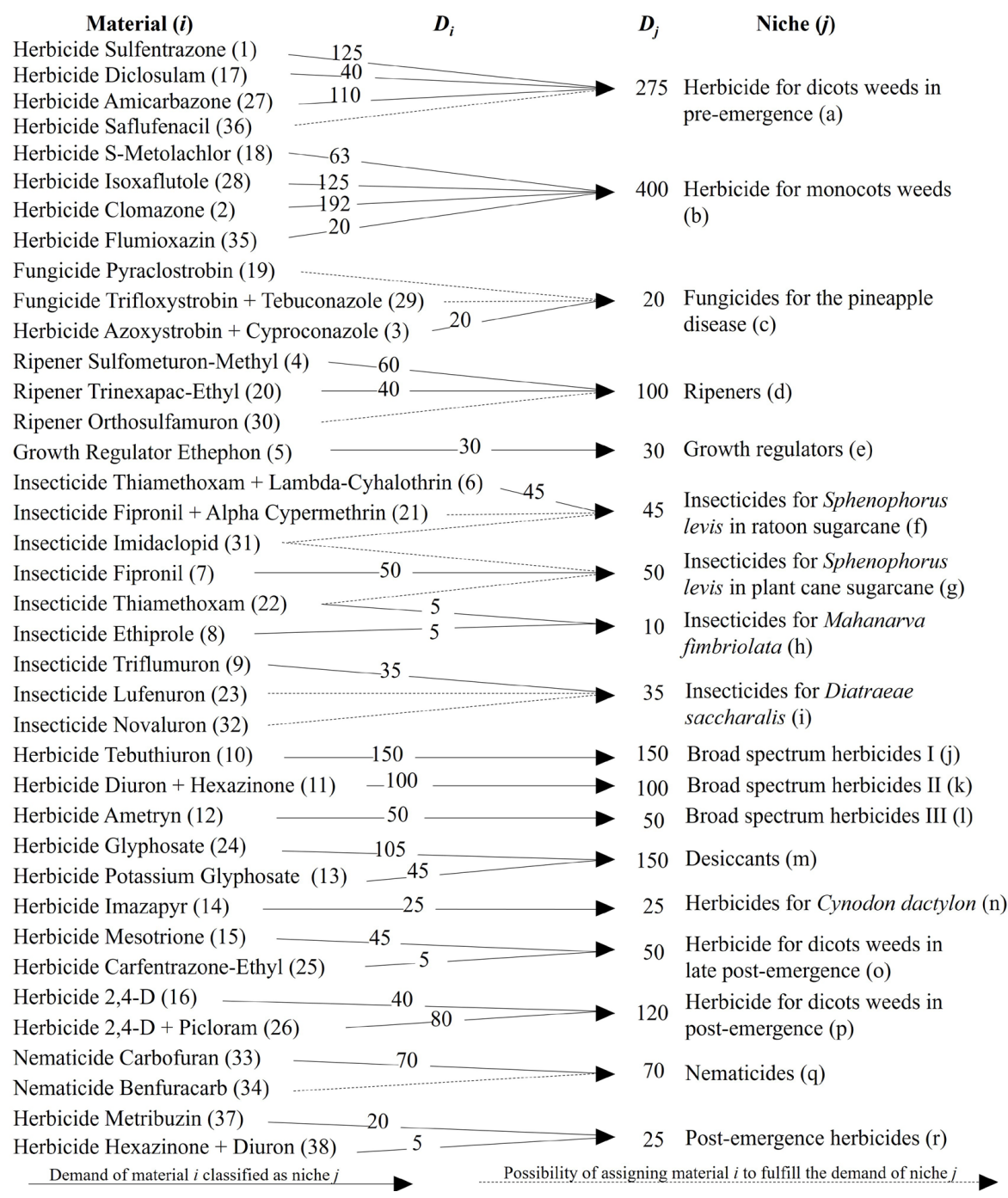

Figure 2. Classification and grouping of demand in purpose niches. 
competition amongst different materials and suppliers. To be successful in this step, it is essential to have in depth knowledge of agriculture (C) and to build a cooperative environment with the crop production department (B).

Secondly, maximum and minimum usage parameters are defined for each product $i$ in each niche $j$ (Figure 3 ). This procedure allows the model to consider other utility peculiarities that are not covered by $D E_{i j k}$. An herbicide $i$, for example, may have its effectiveness reduced in dry conditions. In this case, the area subjected to these circumstances in niche $j$ should be estimated and the parameter $\operatorname{Max}_{i j}$ defined excluding this extent. This is a promising environment for unilateral, conservative decisions by the technical department. Therefore, to preserve the potential benefits of the approach for the whole organization, an empowered mediation performed by purchasing is necessary, supporting D's relevance for the feasibility of the framework.

In order to take advantage of potential economies of scope and scale, suppliers are encouraged to make two different proposals: the first $(l=1)$, a spot acquisition proposal, where the sugarcane mill selects products and volumes at its own convenience and the second $(l=2)$, a portfolio acquisition proposal, which specifies products and their respective minimum volumes of acquisition $\left(P P_{i k}\right)$. It is important to notice that, in the latter, the proposal can only be accepted if the order assigned to the supplier is equal to or greater than $P P_{i k}$ for all agrochemicals included in the contract. In addition, to guarantee the practical feasibility of the model, real world operational restrictions like supply capacity $\left(C F_{i k}\right)$, package contents $\left(E_{i j k}\right)$ and minimum order $\left(F_{\min }\right)$ are stated (Table 2). To avoid disruptions in supply and to reserve some

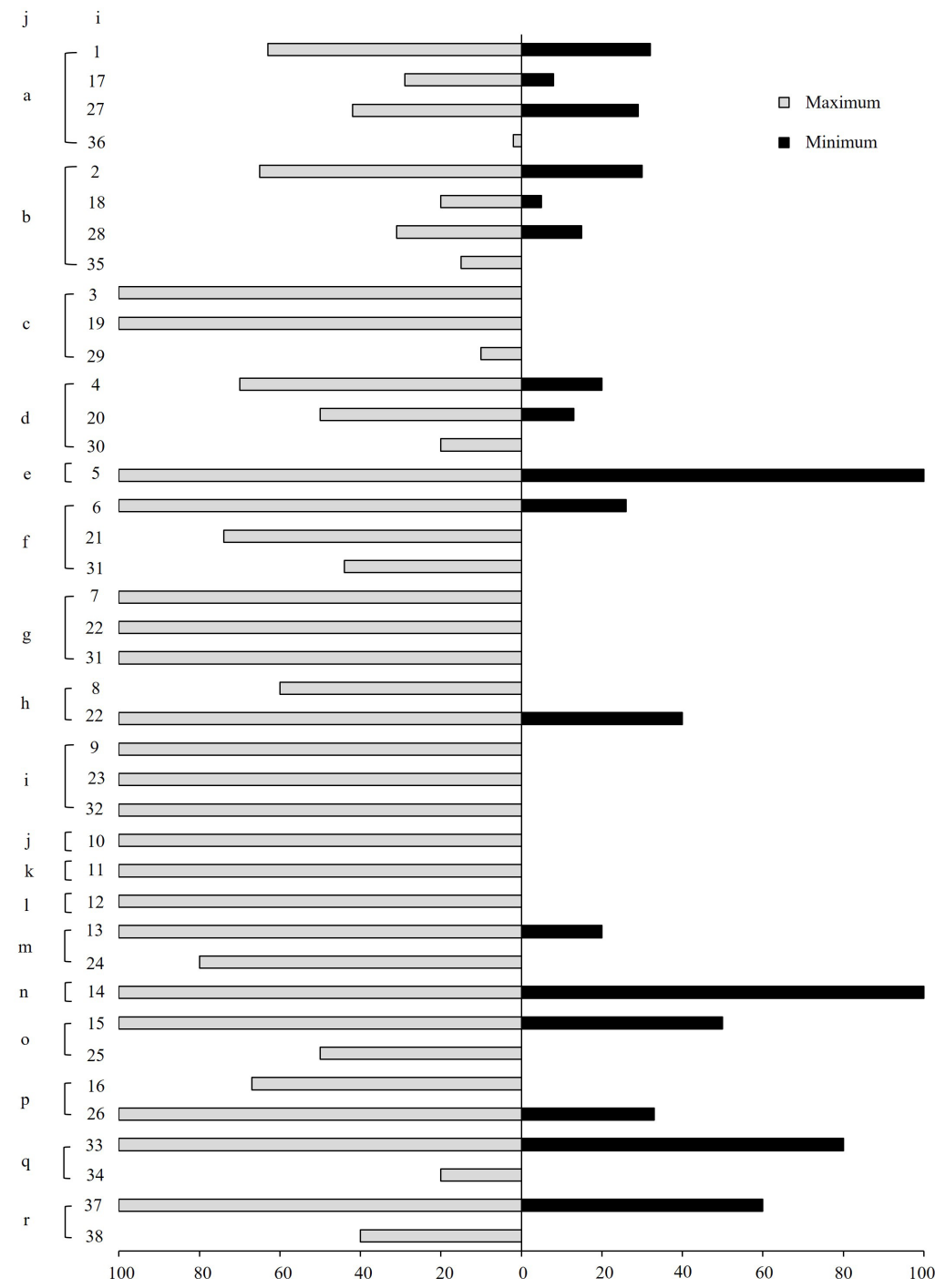

Figure 3. Maximum and minimum usage of materials in their corresponding purpose niches. 
Table 2. Proposals parameters and operational limitations.

\begin{tabular}{|c|c|c|c|c|c|c|c|c|}
\hline$k$ & Fmín $_{k(\mathrm{RS})}$ & $i$ & $P P_{i k(10}{ }^{3}$ units) & $C F_{i k(10}{ }^{3}$ units) & $j$ & $E_{i j k \text { (hectares/unit) }}$ & $P_{i j k l(\mathrm{RS} / \text { hectare })}$ & $P_{i j k 2 \text { (RS/hectare) }}$ \\
\hline \multirow[t]{5}{*}{ I } & $200,000.00$ & 1 & 15.00 & 27.50 & $\mathbf{a}$ & 10 & 49.76 & 45.00 \\
\hline & & 2 & 52.00 & 80.00 & b & 5 & 24.73 & 22.25 \\
\hline & & 30 & 4.00 & 20.00 & d & 5 & 15.00 & 13.00 \\
\hline & & 25 & 2.00 & 10.00 & $\mathbf{0}$ & 5 & 8.02 & 7.22 \\
\hline & & 33 & 14.00 & 14.00 & $\mathbf{q}$ & 5 & 53.82 & 48.42 \\
\hline \multirow[t]{9}{*}{ II } & $100,000.00$ & 18 & 12.80 & 80.00 & $\mathbf{b}$ & 5 & 21.75 & 20.50 \\
\hline & & 3 & 1.00 & 1.00 & c & 20 & 6.75 & 5.75 \\
\hline & & 20 & 2.50 & 10.00 & d & 10 & 22.32 & 20.16 \\
\hline & & 6 & 9.00 & 9.00 & f & 5 & 42.88 & 36.75 \\
\hline & & 22 & 2.00 & 2.00 & g & 5 & 35.10 & 31.50 \\
\hline & & 22 & 2.00 & 2.00 & $\mathbf{h}$ & 5 & 35.10 & 31.50 \\
\hline & & 23 & 3.00 & 7.00 & i & 5 & 1.20 & 1.20 \\
\hline & & 12 & 10.00 & 10.00 & I & 5 & 25.00 & 20.50 \\
\hline & & 15 & 2.00 & 2.50 & $\mathbf{0}$ & 20 & 9.40 & 9.00 \\
\hline \multirow[t]{8}{*}{ III } & $200,000.00$ & 28 & 125.00 & 400.00 & b & 1 & 15.84 & 14.88 \\
\hline & & 29 & 0.40 & 4.00 & c & 5 & 13.00 & 12.00 \\
\hline & & 5 & 1.50 & 1.50 & e & 20 & 35.20 & 33.10 \\
\hline & & 31 & 9.00 & 9.00 & f & 5 & 33.60 & 27.00 \\
\hline & & 31 & 9.00 & 9.00 & $\mathbf{g}$ & 5 & 33.60 & 27.00 \\
\hline & & 8 & 2.00 & 2.00 & h & 5 & 56.44 & 51.00 \\
\hline & & 9 & 3.50 & 3.50 & $\mathbf{i}$ & 10 & 2.35 & 2.10 \\
\hline & & 37 & 2.00 & 5.00 & $\mathbf{r}$ & 5 & 42.00 & 40.25 \\
\hline \multirow[t]{5}{*}{ IV } & $200,000.00$ & 36 & 1.00 & 55.00 & $\mathbf{a}$ & 5 & 20.40 & 19.40 \\
\hline & & 19 & 1.00 & 2.00 & c & 10 & 15.00 & 14.00 \\
\hline & & 21 & 2.00 & 4.50 & f & 10 & 35.20 & 30.00 \\
\hline & & 7 & 10.00 & 10.00 & g & 5 & 21.25 & 19.50 \\
\hline & & 14 & 5.00 & 5.00 & $\mathbf{n}$ & 5 & 76.00 & 71.00 \\
\hline \multirow[t]{6}{*}{ IX } & $50,000.00$ & 35 & 3.00 & 5.00 & $\mathbf{b}$ & 20 & 26.75 & 25.50 \\
\hline & & 31 & 9.00 & 9.00 & f & 5 & 29.40 & 28.00 \\
\hline & & 31 & 9.00 & 9.00 & g & 5 & 29.40 & 28.00 \\
\hline & & 16 & 4.00 & 8.00 & $\mathbf{p}$ & 10 & 3.30 & 3.10 \\
\hline & & 26 & 16.00 & 24.00 & $\mathbf{p}$ & 5 & 5.60 & 5.50 \\
\hline & & 13 & 15.00 & 15.00 & m & 10 & 15.75 & 15.75 \\
\hline \multirow[t]{4}{*}{$\mathbf{V}$} & $100,000.00$ & 17 & 80.00 & 275.00 & $\mathbf{a}$ & 1 & 45.99 & 43.47 \\
\hline & & 10 & 10.00 & 10.00 & $\mathbf{j}$ & 5 & 19.80 & 17.10 \\
\hline & & 3 & 1.00 & 2.00 & c & 10 & 6.50 & 6.50 \\
\hline & & 26 & 8.00 & 12.00 & p & 10 & 6.75 & 6.30 \\
\hline \multirow[t]{3}{*}{ VI } & $100,000.00$ & 4 & 3.50 & 5.00 & d & 20 & 19.50 & 18.80 \\
\hline & & 11 & 4.00 & 4.00 & $\mathbf{k}$ & 10 & 20.00 & 18.00 \\
\hline & & 38 & 25.00 & 25.00 & $\mathbf{r}$ & 1 & 20.00 & 18.75 \\
\hline \multirow[t]{8}{*}{ VII } & $50,000.00$ & 2 & 20.00 & 20.00 & b & 10 & 21.88 & 21.40 \\
\hline & & 7 & 10.00 & 10.00 & g & 5 & 20.00 & 17.50 \\
\hline & & 32 & 4.00 & 4.00 & $\mathbf{i}$ & 5 & 2.10 & 2.10 \\
\hline & & 10 & 30.00 & 30.00 & $\mathbf{j}$ & 5 & 19.80 & 18.90 \\
\hline & & 11 & 10.00 & 10.00 & k & 10 & 19.60 & 19.00 \\
\hline & & 16 & 8.00 & 12.00 & p & 10 & 3.20 & 3.20 \\
\hline & & 38 & 10.00 & 25.00 & $\mathbf{r}$ & 1 & 21.25 & 19.75 \\
\hline & & 24 & 24.00 & 30.00 & $\mathbf{m}$ & 5 & 16.80 & 15.00 \\
\hline
\end{tabular}

$\mathrm{k}=$ Suppliers; $\mathrm{i}=$ Products; $\mathrm{j}=$ Purpose niches; $F_{\min }{ }_{k}=$ Minimum order to supplier $k ; E_{i j k}=$ Package content of product $i$, in niche $j$, by supplier $k ; C F_{i k}=$ Supply capacity of product $i$ by supplier $k ; P P_{i k}=$ Portfolio proposal of product $i$ by supplier $k ; P_{i j k l}=$ Volume acquired of product $i$, for niche $j$, from supplier $k$, in the proposal $1 ; P_{i j k 2}=$ Volume acquired of product $i$, for niche $j$, from supplier $k$, in the proposal 2. Source: Elaborated by the authors. 
Table 2. Continued...

\begin{tabular}{|c|c|c|c|c|c|c|c|c|}
\hline$k$ & Fmín $_{k(\mathrm{RS})}$ & $i$ & $P P_{i k(10}^{3}$ units) & $C F_{i k(10}{ }^{3}$ units $)$ & $j$ & $E_{i j k \text { (hectares/unit) }}$ & $P_{i j k I(\mathrm{R} \$ / \text { hectare })}$ & $P_{i j k 2(\mathrm{RS} / \text { hectare) }}$ \\
\hline \multirow[t]{8}{*}{ VIII } & $50,000.00$ & 7 & 1.50 & 1.50 & g & 20 & 17.50 & 17.00 \\
\hline & & 31 & 3.00 & 3.00 & f & 5 & 26.60 & 24.00 \\
\hline & & 31 & 3.00 & 3.00 & $\mathbf{g}$ & 5 & 26.60 & 24.00 \\
\hline & & 10 & 30.00 & 30.00 & $\mathbf{j}$ & 5 & 19.80 & 18.00 \\
\hline & & 12 & 10.00 & 10.00 & 1 & 5 & 22.50 & 21.00 \\
\hline & & 11 & 10.00 & 10.00 & $\mathbf{k}$ & 10 & 19.40 & 17.70 \\
\hline & & 37 & 5.00 & 5.00 & $\mathbf{r}$ & 5 & 35.00 & 34.30 \\
\hline & & 24 & 24.00 & 30.00 & $\mathbf{m}$ & 5 & 15.00 & 15.00 \\
\hline \multirow[t]{3}{*}{$\mathbf{X}$} & $200,000.00$ & 27 & 5.75 & 13.75 & $\mathbf{a}$ & 20 & 36.30 & 32.00 \\
\hline & & 10 & 10.00 & 15.00 & $\mathbf{j}$ & 10 & 18.90 & 18.54 \\
\hline & & 26 & 24.00 & 24.00 & p & 5 & 5.70 & 5.40 \\
\hline \multirow[t]{2}{*}{$\mathbf{X I}$} & $70,000.00$ & 35 & 3.00 & 20.00 & b & 20 & 26.25 & 25.00 \\
\hline & & 34 & 2.80 & 10.00 & $\mathbf{q}$ & 5 & 81.15 & 67.50 \\
\hline \multirow[t]{2}{*}{ XII } & $200,000.00$ & 13 & 20.00 & 30.00 & m & 5 & 17.10 & 16.65 \\
\hline & & 24 & 10.00 & 30.00 & m & 5 & 15.00 & 14.40 \\
\hline \multirow[t]{6}{*}{ XIII } & $30,000.00$ & 31 & 9.00 & 9.00 & f & 5 & 28.50 & 26.60 \\
\hline & & 31 & 9.00 & 9.00 & g & 5 & 28.00 & 26.30 \\
\hline & & 7 & 10.00 & 10.00 & g & 5 & 20.00 & 17.50 \\
\hline & & 11 & 10.00 & 10.00 & k & 10 & 19.60 & 18.00 \\
\hline & & 16 & 4.00 & 4.00 & p & 10 & 3.00 & 2.80 \\
\hline & & 24 & 24.00 & 30.00 & m & 5 & 15.00 & 15.00 \\
\hline
\end{tabular}

$\mathrm{k}=$ Suppliers $; \mathrm{i}=$ Products; $\mathrm{j}=$ Purpose niches Fmin $_{k}=$ Minimum order to supplier $k ; E_{i j k}=$ Package content of product $i$, in niche $j$, by supplier $k ; C F_{i k}=$ Supply capacity of product $i$ by supplier $k ; P P_{i k}=$ Portfolio proposal of product $i$ by supplier $k ; P_{i j k l}=$ Volume acquired of product $i$, for niche $j$, from supplier $k$, in the proposal $1 ; P_{i j k 2}=$ Volume acquired of product $i$, for niche $j$, from supplier $k$, in the proposal 2. Source: Elaborated by the authors.

reward power to future negotiations (Monczka et al., 2015), it is advisable that $P P_{i k} \leq C F_{i k} \forall i \in I, \forall k \in k$ and $P P_{i k}<\sum_{j}^{m} \frac{M a ́ x_{i j}}{E_{i j k}} \forall i \in I, \forall k \in K$. Stimulating portfolio-based proposals can lead the model to reduce significantly the supplier base, a risky step to be taken. Clearness about the convenience and the right partners for doing so is capital (E).

It is important to highlight that the agrochemicals utility patterns $\left(D E_{i j k}\right)$ are their relative efficiency on producing Total Recoverable Sugars (ATR) when compared to the best in class of their niches (Figure 4). Sugarcane's most important productivity indicator is the amount of ATR obtained in one hectare. Using one insecticide instead of another, for example, can be less effective in the pest controlling process, culminating in lower yields. This analysis is made for all of them. The higher scores for each niche are considered to be $100 \%$ efficient and the others are calculated relatively to them.

Finally, such methodology can only be thought and structured by a purchasing area sufficiently experimented in decision analysis tools, emphasizing the importance of A as a basis for the model.

\subsection{Outcomes analysis}

To assess the results obtained with the proposed approach, we have ran three different stages of the model in an evolutionary way: (I) Traditional model, represented by equations (1) and (2) associated to the operational restrictions from (17) to (20) with the necessary adaptations; (II) "Reduced approach, in which demand relaxation is conducted by equations (7) to (10) and linked to operational restrictions from (17) to (20) with the necessary adaptations, ignoring possible economies derived from scope and scale; (III) Full Approach, covering equations from (7) à (20) excluding (11) and (12). With that, it is possible to evaluate the impacts of each step of the approach conception in the final results (Figure 5).

The figure allows objective conclusions about the employed methods. The so-called inescapable acquisitions are those which involve products initially ordered by the technical department that do not have competitors, in this case, patented agrochemicals. Organizing demand in purpose niches introduces competition in their hitherto comfortable market-share. The decline in almost $35.0 \%$ in these acquisitions explains the cost reduction of $3.0 \%$ observed from the traditional model to the reduced approach. The contract's concentration is given by the percentage of total expenditure allocated to the top 5 suppliers. The conceptual application of combinatorial auctions raised concentration to over $85.0 \%$. This, in turn, provoked a decrease in total costs of more than $2.5 \%$. Finally, the average utility of the acquisition packages in each step registered almost imperceptible variations, enhancing the 


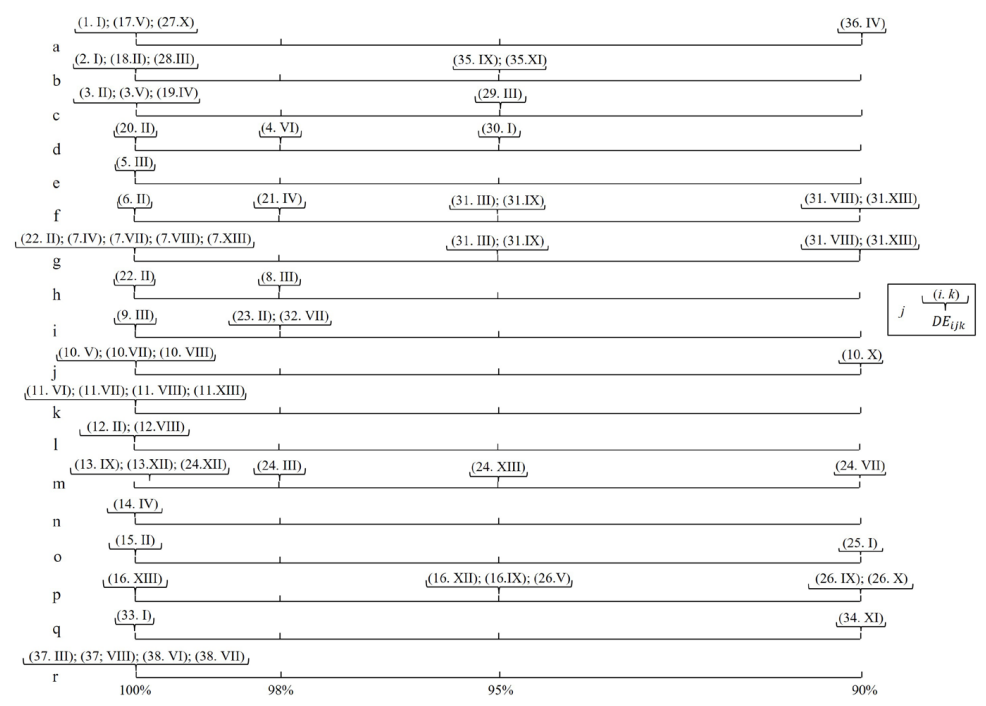

Figure 4. Comparative utility of the products in their niches.

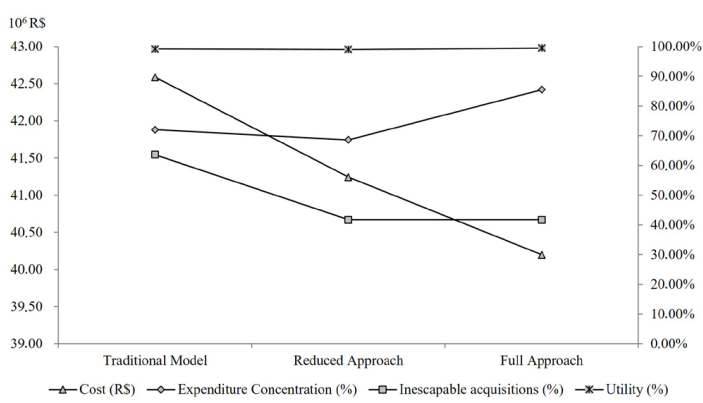

Figure 5. Cost, utility, inescapable acquisitions and expenditure concentration in traditional model, reduced approach and full approach.

confidence for making the bold decisions the full approach proposed.

Also, two negotiation opportunities are open to exploitation in this approach: coercive and reward power (Monczka et al., 2015). Since monopolies are broken and contract's concentration is encouraged, it is likely that some suppliers that used to have robust sales in the past are now threatened. This is a very fruitful scenario to require cost reduction and increased service levels. The reward power can be used if the conditions mentioned in section 4.1 are respected. They allow the parameter $P P_{i k}$ to be raised until $\sum_{j}^{m} \frac{M a x_{i j}}{E_{i j k}}$. This can be the rabbit pulled out of the hat for a successful agreement.

\section{Conclusions}

The focus of this research was to evaluate the impacts in cost and utility of demand relaxation. The results have shown that rearranging demand is as potentially effective for cost reduction as economies of scope and scale. In this sense, the idea of buying objectives rather than pre-determined materials opens a universe of possibilities as unknown as promising. Utility's irrelevant fluctuation highlights the feasibility of the approach proposed, although in this point we reaffirm that careful attention has to be devoted into the definition and assessment of this criterion. Finally, we have tried to empirically point out the main requirements for the application of this framework in a purchasing department.

The paper's contribution is threefold: first, it introduces a discussion that is mostly neglected in the purchasing literature. All models' efficiency in selecting suppliers may be undermined if the "original sin" is the mistaken definition of what is actually needed. Aware of that, an initial step is taken towards this conception with a model to analyze its potential for cost reduction. Secondly, it ties the mathematical programming approach for vendor selection and demand relaxation with purchasing's organizational structure. Although this is done empirically, it appears to be important for a business-driven research to point out the requirements for their findings to be applied in a real world situation. Lastly, the model is an interesting option for purchasing environments in which there are multiple products, multiple suppliers and the presence of patented materials, like the pharmaceutical or crop's nutrition industry.

On the other hand, the study has important limitations as well. Demand is treated as being deterministic, while it is actually stochastic in the majority of practical situations. This may result in optimal planning and sub optimal execution. Also, no solution is pointed out to reduce the subjectivity of qualitative criteria. The utility parameter is fragile and its definition depends largely on the clearness 
of the staff involved about what really matters for decision making. This conjecture may block a more clear observation of the impacts of the approach on utility. Costs could have a wider coverage than the model has given.

These weaknesses indicate some of the pathways for future research. The model could be formulated as a Goal Programming. Soft restrictions would give interesting insights for negotiation with suppliers as well as for min-max parameters settlement. Reducing subjectivity and broaden the qualitative criteria can give a much stronger reliability to the model. Although they also carry some subjectivity, multiattribute utility methods could be employed for a comparison of results. Stochastic Programming to deal with variable, unpredictable demand can also be of great value. Costs could be further explored as well, including transaction, inventory and application costs, for instance. Finally, this methodology was thought based on practical experiences acquired in low-medium added value industries, where purchasing still has a cost driven role. In that sense, it would be interesting to apply these concepts in an industry where other features have a protagonist role to assess if the framework preserves its effectiveness.

\section{References}

Amin, S. H., \& Zhang, G. (2012). An integrated model for closed-loop supply chain configuration and supplier selection: multi-objective approach. Expert Systems with Applications, 39(8), 6782-6791. http://dx.doi. org/10.1016/j.eswa.2011.12.056.

Benton, W. C., \& Park, S. (1996). A classification of literature on determining the lot size under quantity discounts. European Journal of Operational Research, 92(2), 219238. http://dx.doi.org/10.1016/0377-2217(95)00315-0.

Brandmeier, R. A., \& Rupp, F. (2010). Benchmarking procurement functions: causes for superior performance. Benchmarking, 17(1), 5-26. http://dx.doi.org/10.1108/14635771011022299.

Caniato, F., Ronchi, S., Luzzini, D., \& Brivio, O. (2015). Total cost of ownership along the supply chain: a model applied to the tinting industry. Production Planning and Control, 26(6), 427-437. http://dx.doi.org/10.1080/095 37287.2014.918285.

Carter, J. R., \& Narasimhan, R. (1996). Is purchasing really strategic? The Journal of Supply Chain Management, 32(4), 20-28.

Catalán, J., Epstein, R., Guajardo, M., Yung, D., \& Martınez, C. (2009). Solving multiple scenarios in a combinatorial auction. Computers \& Operations Research, 36(10), 2752-2758. http://dx.doi.org/10.1016/j.cor.2008.12.006.

Chai, J., Liu, J. N., \& Ngai, E. W. (2013). Application of decision-making techniques in supplier selection: a systematic review of literature. Expert Systems with Applications, 40(10), 3872-3885. http://dx.doi.org/10.1016/j. eswa.2012.12.040.
Chen, I. J., Paulraj, A., \& Lado, A. A. (2004). Strategic purchasing, supply management, and firm performance. Journal of Operations Management, 22(5), 505-523. http://dx.doi.org/10.1016/j.jom.2004.06.002.

Christopher, M. (2012). Managing supply chain complexity: identifying the requisite skills. Supply Chain Forum: An International Journal, 13(2), 4-9. http://dx.doi.org/10.1 080/16258312.2012.11517288.

Cousins, P. D. (1999). Supply base rationalisation: myth or reality? European Journal of Purchasing \& Supply Management, 5(3), 143-155. http://dx.doi.org/10.1016/ S0969-7012(99)00019-2.

De Boer, L., Labro, E., \& Morlacchi, P. (2001). A review of methods supporting supplier selection. European Journal of Purchasing \& Supply Management, 7(2), 75-89. http:// dx.doi.org/10.1016/S0969-7012(00)00028-9.

Degraeve, Z., \& Roodhooft, F. (1999). Effectively selecting suppliers using total cost of ownership. The Journal of Supply Chain Management, 35(4), 5-10. http://dx.doi. org/10.1111/j.1745-493X.1999.tb00050.x.

Derwik, P., Hellström, D., \& Karlsson, S. (2016). Manager competences in logistics and supply chain practice. Journal of Business Research, 69(11), 4820-4825. http:// dx.doi.org/10.1016/j.jbusres.2016.04.037.

Driedonks, B. A., Gevers, J. M., \& van Weele, A. J. (2014). Success factors for sourcing teams: how to foster sourcing team effectiveness. European Management Journal, 32(2), 288-304. http://dx.doi.org/10.1016/j.emj.2013.01.009.

Dubey, R., \& Gunasekaran, A. (2015). Supply chain talent: the missing link in supply chain strategy. Industrial and Commercial Training, 47(5), 257-264. http://dx.doi. org/10.1108/ICT-11-2014-0073.

Dweiri, F., Kumar, S., Khan, S. A., \& Jain, V. (2016). Designing an integrated AHP based decision support system for supplier selection in automotive industry. Expert Systems with Applications, 62, 273-283. http:// dx.doi.org/10.1016/j.eswa.2016.06.030.

Ellinger, A. E., Natarajarathinam, M., Adams, F. G., Gray, J. B., Hofman, D., \& O’Marah, K. (2011). Supply chain management competency and firm financial success. Journal of Business Logistics, 32(3), 214-226. http:// dx.doi.org/10.1111/j.2158-1592.2011.01018.x.

Ellram, L. M. (1995). Total cost of ownership: an analysis approach for purchasing. International Journal of Physical Distribution \& Logistics Management, 25(8), 4-23. http:// dx.doi.org/10.1108/09600039510099928.

Flynn, B. B., Huo, B., \& Zhao, X. (2010). The impact of supply chain integration on performance: a contingency and configuration approach. Journal of Operations Management, 28(1), 58-71. http://dx.doi.org/10.1016/j. jom.2009.06.001.

Gadde, L. E., \& Håkansson, H. (1994). The changing role of purchasing: reconsidering three strategic issues. European Journal of Purchasing \& Supply Management, 1(1), 27 35. http://dx.doi.org/10.1016/0969-7012(94)90040-X. 
Ghodsypour, S. H., \& O’Brien, C. (1998). A decision support system for supplier selection using an integrated analytic hierarchy process and linear programming. International Journal of Production Economics, 56, 199-212. http:// dx.doi.org/10.1016/S0925-5273(97)00009-1.

González-Benito, J. (2007). A theory of purchasing's contribution to business performance. Journal of Operations Management, 25(4), 901-917. http://dx.doi. org/10.1016/j.jom.2007.02.001.

Heckmann, P., Shorten, D., \& Engel, H. (2003). Supply chain management at 21. Transportation \& Distribution, 19, 1-9.

Ho, W., Xu, X., \& Dey, P. K. (2010). Multi-criteria decision making approaches for supplier evaluation and selection: a literature review. European Journal of Operational Research, 202(1), 16-24. http://dx.doi.org/10.1016/j. ejor.2009.05.009.

Hohner, G., Rich, J., Ng, E., Reid, G., Davenport, A. J., Kalagnanam, J. R., Lee, H. S., \& An, C. (2003). Combinatorial and quantity-discount procurement auctions benefit Mars, Incorporated and its suppliers. Interfaces, 33(1), 23-35. http://dx.doi.org/10.1287/inte.33.1.23.12717.

Jadidi, O. M. I. D., Zolfaghari, S., \& Cavalieri, S. (2014). A new normalized goal programming model for multiobjective problems: A case of supplier selection and order allocation. International Journal of Production Economics, 148, 158-165. http://dx.doi.org/10.1016/j. ijpe.2013.10.005.

Jayaraman, V., Srivastava, R., \& Benton, W. C. (1999). Supplier selection and order quantity allocation: a comprehensive model. The Journal of Supply Chain Management, 35(1), 50-58. http://dx.doi.org/10.1111/j.1745-493X.1999. tb00237.x.

Lambert, D. M., Emmelhainz, M. A., \& Gardner, J. T. (1996). Developing and implementing supply chain partnerships. International Journal of Logistics Management, 7(2), 1-18. http://dx.doi.org/10.1108/09574099610805485.

Lin, C. T., Chen, C. B., \& Ting, Y. C. (2011). An ERP model for supplier selection in electronics industry. Expert Systems with Applications, 38(3), 1760-1765. http:// dx.doi.org/10.1016/j.eswa.2010.07.102.

Monczka, R. M., Handfield, R. B., Giunipero, L. C., \& Patterson, J. L. (2015). Purchasing and supply chain management. Boston: Cengage Learning.

Narasimhan, R., \& Das, A. (2001). The impact of purchasing integration and practices on manufacturing performance. Journal of Operations Management, 19(5), 593-609. http://dx.doi.org/10.1016/S0272-6963(01)00055-9.

Pan, A. C. (1989). Allocation of order quantity among suppliers. The Journal of Supply Chain Management, 25(3), 36-39.

Pearson, J. N., \& Gritzmacher, K. J. (1990). Integrating purchasing into strategic management. Long Range Planning, 23(3), 91-99. http://dx.doi.org/10.1016/00246301(90)90057-B.
Reck, R. F., \& Long, B. G. (1988). Purchasing: a competitive weapon. The Journal of Supply Chain Management, 24(3), 2.

Sonmez, M. (2006). Review and critique of supplier selection process and practices. Loughborough: Loughborough University.

Stank, T. P., Paul Dittmann, J., \& Autry, C. W. (2011). The new supply chain agenda: a synopsis and directions for future research. International Journal of Physical Distribution \& Logistics Management, 41(10), 940-955. http://dx.doi.org/10.1108/09600031111185220.

Swink, M., \& Schoenherr, T. (2015). The effects of crossfunctional integration on profitability, process efficiency, and asset productivity. Journal of Business Logistics, 36(1), 69-87. http://dx.doi.org/10.1111/jbl.12070.

Van Hoek, R., \& Wagner, B. (2013). Supply Chain Management (SCM): current education provision and practitioner future needs. Supply Chain Management, 18(4). http:// dx.doi.org/10.1108/scm.2013.17718daa.001.

Van Weele, A. J., Rozemeijer, F. A., \& Rietveld, G. (1998, April). Professionalizing purchasing organization: toward a purchasing development model. In Proceedings 7 th IPSERA Conference (pp. 515-523). London: IPSERA.

Wadhwa, V., \& Ravindran, A. R. (2007). Vendor selection in outsourcing. Computers \& Operations Research, 34(12), 3725-3737. http://dx.doi.org/10.1016/j.cor.2006.01.009.

Wagner, S. M., \& Kemmerling, R. (2014). Supply chain management executives in corporate upper echelons. Journal of Purchasing and Supply Management, 20(3), 156-166. http://dx.doi.org/10.1016/j.pursup.2014.01.006.

Walterbusch, M., Martens, B., \& Teuteberg, F. (2013). Evaluating cloud computing services from a total cost of ownership perspective. Management Research Review, 36(6), 613-638. http://dx.doi.org/10.1108/01409171311325769.

Weber, C. A., \& Current, J. R. (1993). A multiobjective approach to vendor selection. European Journal of Operational Research, 68(2), 173-184. http://dx.doi. org/10.1016/0377-2217(93)90301-3.

Xia, W., \& Wu, Z. (2007). Supplier selection with multiple criteria in volume discount environments. Omega, 35(5), 494-504. http://dx.doi.org/10.1016/j.omega.2005.09.002.

Yu, C., \& Wong, T. N. (2015). An agent-based negotiation model for supplier selection of multiple products with synergy effect. Expert Systems with Applications, 42(1), 223-237. http://dx.doi.org/10.1016/j.eswa.2014.07.057.

Yu, C., Wong, T. N., \& Li, Z. (2017). A hybrid multi-agent negotiation protocol supporting supplier selection for multiple products with synergy effect. International Journal of Production Research, 55(1), 18-37. http:// dx.doi.org/10.1080/00207543.2016.1189105.

Zheng, J., Knight, L., Harland, C., Humby, S., \& James, K. (2007). An analysis of research into the future of purchasing and supply management. Journal of Purchasing and Supply Management, 13(1), 69-83. http://dx.doi. org/10.1016/j.pursup.2007.03.004. 